\title{
The influence of climate change on food innovation technology: review on topical developments and legal framework
}

\author{
Kingsley Eghonghon Ukhurebor ${ }^{1 *}$ (D) and Paul Atagamen Aidonojie ${ }^{2}$
}

\begin{abstract}
The influence of climate change on agriculture, especially as it relates to the production of food, changes with reverence to duration and space, of which most of these influences are diverse and remarkably uncertain. Undoubtedly, the application of food innovation technology (FIT) in the agricultural processes is an important response for operative and objective adaptation and mitigation of climate change. Consequently, there is a need to urgently re-evaluate the procedures for FIT so as to address the diversities and uncertainties ensuing from these influences of climate change on agriculture with the aim of improving the production of food. Therefore, the application of climate-smart agricultural (CSA) activities with resilience in agricultural events as well as more aids in the application of resources for both in the adaptation and mitigation of climate change by means of FIT will be of great assistance in this regard. Hence, this study presents a facile review of some of the topical developments in the production of food with reverence to the influence of climate change on FIT. Some legal frame-work on climate change with respect to FIT are also been discussed.
\end{abstract}

Keywords: Agricultural processes, Climate change, Food, Resources, Technology

\section{Introduction}

Agricultural processes especially as it relates to the production of food is an important aspect in evolving the economy of any nation [104]. In this present era, agricultural processes and activities are faced with several challenges,according to "the Food and Agriculture Organization (FAO) of the United Nations (UN)," it has to produce additional food and fibre to take care of a rising population, additional feedstocks for a possibly enormous biotechnology market, contribute to the global development in the several agricultural dependent underdeveloped and developing nations, adopt additional sustainable production approaches and adapt to the

\footnotetext{
*Correspondence: ukeghonghon@gmail.com; ukhurebor.

kingsley@edouniversity.edu.ng

${ }^{1}$ Department of Physics, Edo State University Uzairue, P.M.B. 04, Auchi, Edo State, Nigeria

Full list of author information is available at the end of the article
}

present global changes in the climatic conditions [32, 33, 35]. Evidently, climate change has a considerable relationship with agricultural processes and activities; [32, 33, 35]. This relationship, according to Ukhurebor et al. [110, $111]$ is stronger in most developing regions of the world due to the fact that their means of livelihood mostly depend on agricultural processes, and these processes usually depend on the climatic state of such regions.

Climate change is influential in food production processes and activities, especially as it relates to agriculture, and it varies with respect to space and duration [111]. Supposedly, the impacts of food productivity processes are diverse and exceedingly ambiguous $[65,111]$. There are reports presently that shows that some regions such as the Mediterranean basin warm 20.00\% quicker than the universal average and that such regions are one of the foremost climate change flashpoints globally, where it is estimated/projected that about 250 million persons will original author(s) and the source, provide a link to the Creative Commons licence, and indicate if changes were made. The images or other third party material in this article are included in the article's Creative Commons licence, unless indicated otherwise in a credit line to the material. If material is not included in the article's Creative Commons licence and your intended use is not permitted by statutory regulation or exceeds the permitted use, you will need to obtain permission directly from the copyright holder. To view a copy of this licence, visit http://creativecommons.org/licenses/by/4.0/. The Creative Commons Public Domain Dedication waiver (http://creativeco mmons.org/publicdomain/zero/1.0/) applies to the data made available in this article, unless otherwise stated in a credit line to the data. 
undergo water deficiency within the next two decades [32, 33 and 35], and with the present policies, (as well as approaches, laws, guidelines, and strategies), temperatures are anticipated to rise by about $2.20{ }^{\circ} \mathrm{C}$ as against pre-industrial level by the year 2040 [32, 33, 35]. Invariably, the increase in the temperature values will also cause a change in other essential climate/weather variables, such as humidity, pressure, rainfall, etc. [42, 95, 113].

According to reports from the FOA [32, 33, 35], it was alleged that there is scarcely a single region in the world that has all the necessary resources both in terms of human and capital intensities in handling and managing the pace and rate of the changes in the climatic conditions on its own. Hence, joint efforts, especially the ones that are in line with the "Sustainable Development Goals (SDGs)", have to be put in place in fronting these climatic conditions that are now causing serious environmental threats to the entire ecosystem. It is also appropriate to re-evaluate the present policies, approaches, laws, guidelines, and strategies on climate change in the upcoming years.

In light of all these, the application of food innovation technology (FIT) is seen as a way forward for the mitigation and modification of these climatic conditions and their ensuing consequences, specifically as it relate to agriculture. Nonetheless, the application of FIT to agricultural processes and activities alone cannot solve these ensuing consequences of the impacts of the changes in the climatic conditions, because these changes occur rapidly as it takes considerable time to develop appropriate FIT $[111,117]$. Hence, there is a need to identify the present impacts of the changes in the climatic conditions and align current research activities such as FIT that are eco-friendly in breeding varieties that would withstand these impacts of the changes in the climatic conditions. The need for FIT is becoming an essential tool in generating measurement and analysis that are paramount in the precision of environmental hazards that have affected agricultural processes and activities as well as other features of human activities and the ecosystem in general.

Climate change adaptation (CCA) plans entail events that could tolerate the destructive consequences of the changes in the climatic conditions [16]. Hence, CCA strategies such as climate-smart agricultural (CSA) practices, water sustainability, waste management and recycling, flood protection, climate protections, and analytical climate conditions innovation machinery on agricultural processes and activities such as FIT are all essential ingredients that need to be reinvigorated, evolved and developed. Albeit, the emphasis for this present facile review study is on the current developments on the influence of climate change on agricultural processes and activities vis-à-vis FIT drawn mainly from several existing publications and other articles. In addition, some legal frame-work on climate change as it relates to FIT is highlighted. This section is the introductory section (section one), which encompasses the background of the review study. Subsequently, the other sections of this article are structured as follows. Section two deliberate on changes in the climatic conditions and FIT, section three discusses the developments in FIT, section four briefly presents the legal frame-work on climate change with respect to FIT, while section six is the conclusion of the paper, as well as recommendations and future prospects. Figure 1 shows the illustrative design of main parts of the study in form of graphical abstract.

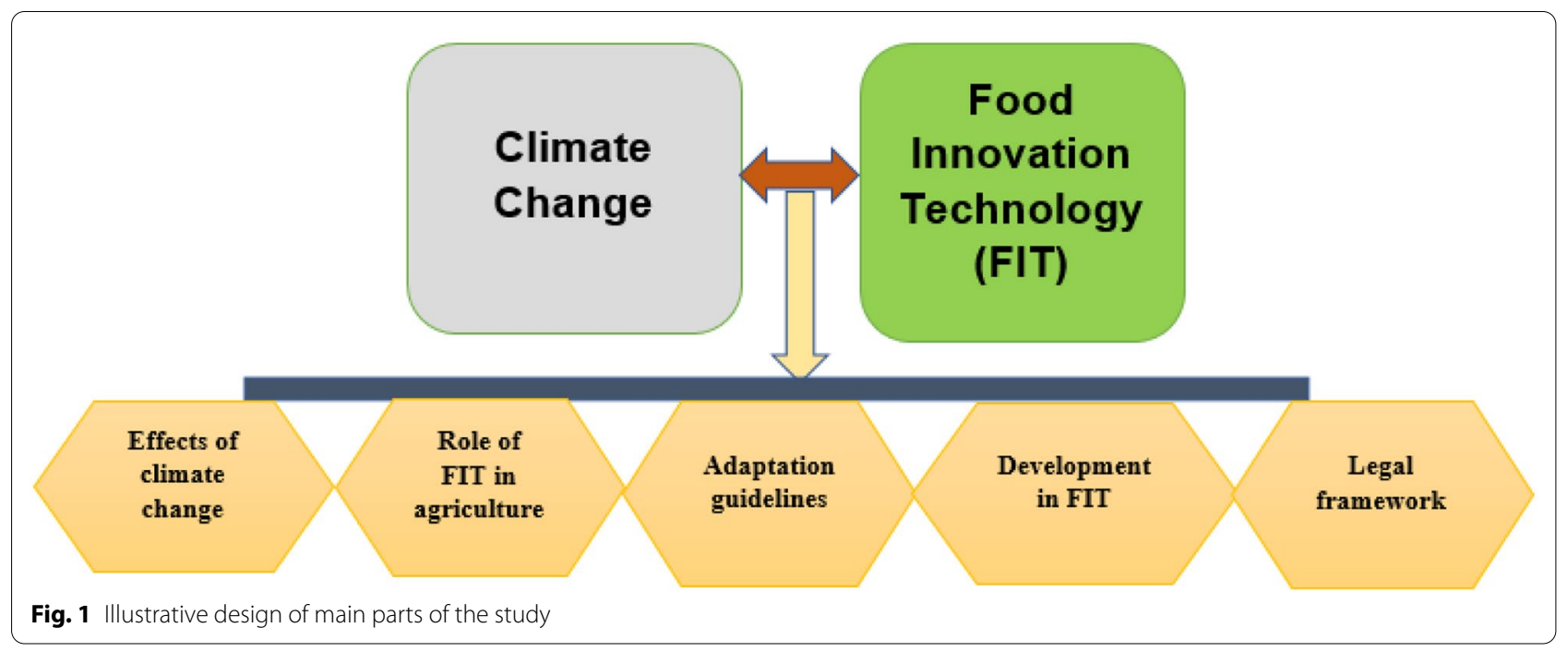




\section{Changes in the climatic conditions and FIT Climate change}

In general, the continuous changes in the climatic conditions have become one of the utmost critical environmental threat that viciously affects not just the agricultural sector but other sectors of human activities as well as the entire ecosystem [70, 71, 94, 106, 117].

Climate change has to do with somewhat variation in the climatic conditions over some duration of time resulting from the changes in a natural process and human actions $[84,104,105]$. Climate change, as reported by the "Intergovernmental Panel on Climate Change (IPCC)," is a change in the climatic process which is attributed directly or indirectly to the activities of humans, that alters the structure and/or composition of the universal atmosphere and which is in accumulation to the natural variability of the climate observed over the comparable duration of time $[48,49]$.

Climate change is an occurrence that could affect any areas and aspects, which could instigate global warming and the modifications in the patterns of precipitations [94]. Arguably, climate change has a stronger impacts on the revenues and economic events, though in diverse settings across nations [49]. It is reported that among such economic events, the agricultural domain is one of the furthermost adversely affected by climate change. Apparently, climate change stances for the long-term modifications, either upsurges or reductions in the atmospheric conditions [94, 95, 104, 105], which is seen as the normal mean weather situations (variables to be specific) such as temperature, humidity, and precipitation, etc. [25]. According to Mendelsohn et al. [63], climate is the study of the "normal or ordinary" climatic or weather variables for an approximate average period of 30 years of the respective climatic or weather variables, while weather entails a very shorten period. However, there some possibility that climate change could be mistakenly termed as weather shocks (which is the deviances of temperature as well as other essential climate variables from historic values, have momentous influences on the economic activities of any nation) or vice visa, and as reported by Gallic and Vermandel [36], this has been inferred as indication of limits to adaptation. It, therefore, to be noted that even when there is difference between climate change and weather shocks, both have effects on food safety, security, and sustainability (FSSS).

\section{Effects of climate change}

Evidently, the effects of climate change are having adverse effects on living organisms and the entire ecosystem (Ziervoge and Ericksen 2010; [77, 104, 107]). Some of these adverse effects are highlighted and outlined below:
Greenhouse gases (GHGs) emissions These gases are mostly the gases that are trap thermal energy (heat) in the atmosphere [2, 75]. When solar energy goes through the air or atmosphere, the GHGs captivate the radiation and avert the ensuing thermal energy from exiting the air, and the process is called the GHG effect [42, 44, 75]. In the absence of GHGs, the earth's average temperature will be extremely cold for the existence of living organisms. Nevertheless, if there is addition of more GHGs to the air as a result of human actions such as deforestation, usage of fuels, domestic and industrial activities, etc. [2,75], and this makes more of the solar energy to get stuck in the air, increasing the temperature of the earth (solar heating) and instigating what is known as global warming [108], Komar and Zeebe [55], which invariably result in changes of the climatic conditions of the earth; hereby contributing considerably to ecological threats and other uncomfortable functionalities in the ecosystem [75]. Nwankwo and Ukhurebor [74, 76, 110], such as the irregularities in the atmospheric radio waves propagations $[109,112,113$, $115]$.

Food safety, security, and sustainability (FSSS) There are several reports on the effects of varying temperatures and precipitations, which are presently affecting agricultural processes, hereby causing a shortage of food (affecting FSSS) and other agricultural resources [52, 111, 112], as well as putting the entire agricultural sector at risk.

According to Sweileh [99] climate change not only threaten humanity and the entire ecosystem but also pose great challenges to FSSS globally. Hence, it is essential to evaluate existing research activities that has to do with FSSS vis-à-vis climate change, and this will optimally be of importance to policymakers and other relevant bodies that are involved with funding and other essentialities for making imminent resolutions. Some research activities outline with respect to FSSS in the framework of climate change have been reported by Sweileh [99] via a bibliographical approach using the Scopus archive for a period of thirty nine (39) years (from 1980 to 2019). The report concluded from the obtained outcome of the study indicate that the issues with FSSS vis-à-vis climate change is a global evolving challenge. Hence, research on innovative technologies for the mitigation of the influences of climate change on FSSS should be a topmost priority. Consequently, research influence and partnership from the various regions of the world with adequate resources must be reinvigorated.

All these are in line with the earlier reported study by Steenwerth et al. [96], where they stated that notwithstanding the varying global climatic conditions as well as the scare opportunities for agricultural development (expansion or growth) on additional agricultural 
lands. They further reported that CSA emphases on contributing to the development and advancement of the economic, reduction of poverty as well as FSSS via the maintenance and enhancement of the efficiency and resilience of agricultural and the entire natural ecosystem functionalities, consequently elevating natural resources and plummeting trade-offs entailed in accompanying these objectives. Allegedly, the existing gaps in knowledge, function within the domain of the CSA, and outlines for interdisciplinary research studies and technological-based activities identified at the "2013 Global Science Conference on CSA" in the USA are defined here within the following themes: agriculture and food structures, landscape and regional concerns and the institution-based and policy traits, and all these themes are within the FSSS domain [96].

Consequently, operational events in the CSA domain would encompass all stakeholders, addressing of the governance concerns, as well as the examination of the uncertainties, the incorporation of social remunerations with technological modifications, and the establishment of climate funding within the green development background. At this point, the socio-ecological procedure is anticipated to moderate the development debates related with the CSA and to categorize technologies, strategies and approaches that could lead to sustainable food production in the context of FIT as well as the consumption outlines in a varying climatic conditions [96].

According to Beddington et al. [11], in the perspective of subsisting the CCA and ensuring FSSS, foremost interventions are necessary for transforming the existing outlines and practices that are essential for the of production of food as well as the distribution and consumption processes. The scientific and technological domain has a critical role to play in apprising contemporary, strategic investments for the establishment of CSA production systems, abate GHGs emissions, make effective utilization of resources, advance truncated-waste supply chains, guarantee suitable nutrition, boost healthy ingestion choices and advance a global knowledge structure for sustainability.

Obliteration of rainforest is an utmost basis from the release of carbon dioxide $\left(\mathrm{CO}_{2}\right)$ Vegetations (such as forests and trees) are recognized as "carbon sinks", since they store $\mathrm{CO}_{2}$ during their growth [65, 75], Komar and Zeebe [55]. During deforestation (cutting down of rainforests) or during the destruction of wildfires, mostly by human activities, large quantities of $\mathrm{CO}_{2}$ are released into the air and environment. Most of the global GHGs emissions instigated by humans are a result of deforestation, especially via bush burning $[45,46]$. Other sources of global GHG emissions are due to the usage of fuel, such as the ones use in vehicles $[45,75]$.

Obliteration of coral reefs These are huge underwater structures comprised mainly of the carcasses of colonial aquatic invertebrates known as coral [27]. Allegedly, in the last three decades, roughly $50.00 \%$ of the coral reefs of the globe have perished. Human actions, as well as extreme weather events such as upsurged temperatures, have contributed meaningly to coral bleaching [83]. When the water becomes extremely warm, as a result of the upsurged temperatures, the algae existing in the coral's tissues depart [83]. Algaegives coral most of its energy; hence coral depends on algae for its survival [62]. Consequently, this would affect other aquatic organisms, such as fish, who make these corals their inhabitant $[38,43,62$, 97].

Weather Due to changes in the climatic conditions, several regions and countries in the world are presently facing extreme weather, such as upsurged temperatures, droughts, unexpected floods, irregular or uncharacteristic rainfall, etc. [41, 104, 105, 107, 114].

Allegedly, the changes in the climate are typically prompted by greenhouse gases (GHGs) accretion in the atmospheric system, resulting in the raise of the consequences of GHGs $[45,46,75]$. GHGs are presently anticipated as one of the utmost causes in the changes of the climatic conditions globally via global warming $[45,46$, 75]. The emission of these GHGs particularly $\mathrm{CO}_{2}$ from the heavy global exploration and exploitation of the main sources of energy (specifically coal and petroleum) products in power plants, housing, industrial activities, transportation as well as in agricultural processes and activities [45, 46, 75]. The upsurge in atmospheric $\mathrm{CO}_{2}$ has habitually been instigated by technologically advanced countries via burning coal and petroleum (oil/ gas) activities (International the News, [47]).

Proper understanding of the changes in the climatic conditions involves studying the weather variables. Due to the persistent dynamic nature of weather, the climate has continuously been a main force of nature that affects mankind in a very convincing manner right from the conception of the universe onwards, and the ensuing impacts are habitually subject to human actions and time. It has constantly been a global apprehension that plays a foremost role in our average lives. Consequently, its unceasing measurement, study, and analysis would conceivably be of great assistance for its mitigation [78, 84, 87].

The application of innovative technology such as FIT in agricultural processes and activities entails the capacity of developing our understanding of the menacing ecological hazards, as well as giving us the state-of-the-art 
approaches, policies, laws (legal frame-work), guidelines, and strategies for the mitigation and management of the incessant changes in the climatic. Currently, through FIT there have been innovative policies and strategies for measuring and plummeting emissions of methane $\left(\mathrm{CH}_{4}\right)$ which is one of the influential GHGs that has produced over 80 times near-term warming influence of $\mathrm{CO}_{2}$ [45, 46, 75]. Reportedly, man-made $\mathrm{CH}_{4}$ emissions are accountable for approximately $25.00 \%$ of the total global warming currently experienced $[55,75,117]$.

\section{Effects of changes in the climatic conditions on agricultural practices}

Global agricultural practices have their peculiar specifics that depend on the conditions of the weather, with the ensuing climate change effects on agricultural practices being tremendously beneficial $[16,34,70,71]$. Presently, climatic peculiarities are not the same as they were previously. Analysing how the ensuing climate change affects agricultural practices, experts in the agricultural sectors have to adopt innovative means such as the CCA guidelines and strategies, as well as CSA.

The global impact of the changes of climate on agriculture forces experts in the agricultural sectors to continuously adjust to the irregular or uncharacteristic weather such as lack of changes in temperature, rainfall, etc. In addition, the effects encompass uncharacteristically hot dry season (summer) and very cold rainy season (winters), or vice versa.

Climate influences agricultural processes and activities; nevertheless, agricultural processes and activities cause changes in the climatic conditions invariably. This occurs as a result of the foremost consequences of field processes such as the emission of GHGs and the exploration of new-fangled lands for agricultural processes and activities [30, 111].

The contribution of agricultural processes and activities to changes in the climatic conditions is enormous and most devastating. As reported by "the United States Environmental Protection Agency (EPA)", agricultural processes and activities are contributing some percentages to GHGs globally, as it contributed about $9.00 \%$ to the overall 2018 GHGs emission in America [30].

The impacts of agricultural processes and activities on the climatic conditions encompasses the following summarized phenomena:

- Biodiversity loss: Biodiversity refers to the degeneration or desertion of biological multiplicity, understood as the diversity of living organisms in the ecosystem. It is the diverse levels of biological classification and their individual genetic unpredictability, as well as the natural outlines present in environ- ment. Biodiversity loss is instigated majorly by loss in habitat, offensive species, and overexploitation of natural resources, pollution, and climate change which also linked with global warming.

- Coastal water contamination and acidification of the aquatic environment: This could be caused mainly by industrial activities, where most industrial waste are dumped in the aquatic environment.

- Deforestation: This refers to the diminution in forest regions around the world as a result of the fact that the said forest is used for other purposes such as agricultural activities, urbanization, or industrial activities. Prominently, deforestation is enhanced by human actions since 1960, and this has been undesirably distressing the natural ecosystems, biodiversity as well the climate systems. The FAO estimates the yearly rate of deforestation to be approximately $1.30 \times 10^{6} \mathrm{~km}^{2}$ in every decade (FOA, 2017b). Reportedly, agriculture activities is the major basis of deforestation (occupying about $80.00 \%$ ), while industrial activities and construction of new structures takes about $15.00 \%$ and urbanization takes about $5.00 \%$. Deforestation have effects on the following; biodiversity, the local populaces and their livelihoods, soil erosion, climate change and well as FSSS,

- Degradation and depletion of the soil: This is another aspect that could be instigated also by industrial activities. Some of the main causes of degradation and depletion of the soil are; deforestation, industrial activities etc.

There is no doubt in the fact that weather variables affect FSSS and hence studying their effects as well as the impacts of climatic conditions on agricultural processes and activities particularly as its relate to FIT is of great need. When the effects of these variables are known, policies that can support the management of the environment can easily be made by policies makers. Hence, there is need to encourage standard researches that are established in the study of climate conditions that have a prominent role to play in FIT for the purpose of FSSS.

\section{The role of innovation technology in agricultural processes and food security}

Changes in the climatic conditions have great consequence on the severity and the extent of the frequency of apprehensions such as increased temperature, drought, increased saline imposition, tropical storms, the existence and magnitude of climate-sensitive pests and infections of both animals and plants [32,33].

There are numerous in genitives in promoting innovative breeds and varieties as well as a population that are resilient to abiotic and biotic apprehensions, which 
are presently encountered universally $[17,34,100]$. The application of agricultural state-of-the-art approaches and devices such as the development of plant multiplicities and crop-microclimate and crop-macroclimate models could be employed for the improvement of plant germplasm improved to imminent climates $[16,90]$. The use of improved germplasm, facts on supplementary discovery ideas, additional proficient and enhanced resource extension services, and the formation of climate data and rural monetary services are all critical [100, 101].

Erratic precipitation patterns and more recurrent extreme weather events are contributing to the interruptions in the entire agricultural sector beneficial [16, $34,70,71]$, especially the ensuing issues of FSSS which is presently confronting every region of the world.

\section{Adaptation guidelines for agriculture and climate change}

As a result of the close relationship between climate change and agriculture, climate change is now of definitive apprehension to experts in the environmental, economic, and agricultural sectors [16]. Experts in these sectors (environmental, economic, and agricultural) need to adjust their practices so as to adapt to the adverse effects they are ongoing as a result of changes in the weather.

Since the influence of contemporary agricultural practices on climate change cannot be undermined/denied; hence, the connexion between climate change and contemporary agricultural practices requires intense attention as the effect are mostly far from beneficial $[16,34]$. Consequently, climate change adaptation (CCA) guidelines and strategies in agricultural practices, as well as mitigation of undesirable effects, are primary responsibilities at the present time for experts in these sectors (environmental, economic, and agricultural). As stated in the introduction section, adaptation strategies on climate change require events that could withstand the detrimental consequences of the changes in the climatic conditions,such CCA strategies include CSA practices, water sustainability, waste management and recycling, flood protection, climate protections and analytical climate conditions innovation machineries on agricultural processes and activities such as FIT.

Weather variations present several issues for those involved in agricultural activities to address, and CCA strategies in agricultural activities are aims of utmost importance [16, 34]. Since CCA and mitigation in agricultural processes are not total solutions,hence, they should be adapted in each specific case. As a possible way of adapting to the changes in the weather conditions, those involved in agricultural activities should consider the climate particulars of their locations, farming potential, and desires, affordability of applied procedures.
Agriculture and CCA are of foremost concern not only to those involved in agricultural activities but other scientists, especially in the biological and environmental domain beneficial [16, 34]. Biological scientists are working to provide agriculturalists with more resistant species that are more tolerant of extreme weather. Ecologists or environmental scientists inspire effective management of the soil by reducing diminution, encouraging carbon appropriation, sparing natural resources, removal of chemical applications, and detrimental emissions.

As per agricultural processes and changes in the climatic conditions, the following summarized procedures would be of great assistance:

- Appropriate and constant preparation to sudden changes in the climatic conditions.

- Ensuring ecosystem compatible drainage system.

- Use of appropriate rainwater harvesting processes.

- Adopting and adapting precision farming processes such as CSA.

- Practicing of field-management processes with no or reduced soil disturbance.

- Use of adaptive plants that are pulsating and resilient to critical climatic conditions.

- Practicing crop modification and rotation approaches.

\section{The influence of climate change on FIT}

There are some clear evidence to believe that climate change is one of the dominant issues for agricultural activities. Some of the effects, previously observed are likely to exaggerate in the near future (especially with the utilization of FIT), contributing to the degenerations in agricultural activities, variations in global market prices, dropping level of food security; implying that there will be a rising level of food insecurity, if appropriate ecofriendly techniques are not put in place [103].

Since, the issue of climate change is not something that can be totally eliminated we have to adapt to it and ensure appropriate eco-friendly techniques for FIT in respect to FSSS. Foremost interventions are also necessary in transforming and evolving existing outlines and practices of FIT in the perspective on the production, distribution and consumption of food for the sole purpose of FSSS. Those involve in scientific research has a vital role to play in apprising contemporaneous, strategic investments in establishing CSA production systems, curtailing GHG emissions, making effective utilization of resources, developing truncated-waste supply chains, ensuring sufficient nutrition, encouraging healthy food consumption choices and developing a comprehensive knowledge structure in FIT for FSSS. 
As rightly reported by Beddington et al. [11], the possible scientific contributions that are critical to the foremost policy recommendations for attaining FSSS in the climate change perspective as proposed by "the Commission on Sustainable Agriculture and Climate Change (CSACC)" are, enhanced understanding of agriculture's susceptibility to climate change, dynamics of food prices, wastage and patterns of consumption of food, monitoring machineries involved in food issues, in addition to multidisciplinary research of locally suitable responses to climate change and FSSS challenges.

FSSS is a key area that has been focused on over the years; several means have be reported and adopted in this regard. Evidently, food scarcities lead to malnutrition which ultimately leads to death especially amongst children and the aging. Hence, researches ought to identify and evaluate climatic condition and their effects on agricultural productivity as well FIT vis-à-vis FSSS as a main means of survival. Since it has be clearly reported that most agricultural yields is determined by higher humidity and lower temperature [95], activities that could lead to the depletion of the ozone layer which may reverse the natural order even if it is in the FIT perception should always be minimized and if possible be totally avoided. Policies that can lead to preservation of the ecosystem in the context of FIT should be developed and such polies should be strictly observed owing to the fact that there can be no prosperous global environment without FSSS.

\section{Developments in FIT}

The global international community has been facing great challenges posed by the depletion and degradation of the environment, which serve as a threat to the existence of mankind and the production of food [14, 26,28, $60,118]$. However, the challenge posed by depletion and degradation of the environment is a result of the growing concern with the rapid rate of climate change, which is adversely affecting the production of food globally $[5,8$, $10,64,98]$. Given this, there is a need to ensure sustainable quality FSSS by devising a means to enhance high quality nutritional and adequate food production [21, 23, $50,86]$. FIT is a global trending topical issue that relate or focuses on how new foods or foods, in general, could be developed, produce and process via innovative technology $[18,54,68,69,89]$.

The essence of FIT is to enhance food quality, food product safety, and security, and especially to use innovative technology to upset the social, cultural, and environmental changes that are currently affecting food production (McCullum [26, 59, 73, 102, 119]. Some of these FIT include but not limited to the following, which are quicker, treatment of soybeans protein with $\mathrm{TiO}_{2}$ photocatalysis to enhance its nutritional value, vitro animal also known as lab-grown meat that produces or grown from stem cells harvested from livestock, which are then cultured in laboratory [19], non-thermal, technological genetically modified rice, high-pressure processing that has the quality of extending the shelf life of food, 3D printing which promotes a healthy high-tech food that redefines how better recipes can be produced and sensory-milder thermal technology.

Furthermore, with innovative food technology, personal and communities want quality food production and FSSS are being guaranteed. Given this, nations within the global environment are currently adopting innovative technology that will enhance quality food production in overcoming global climate change. According to Kourkoutas et al. [56], most developed countries consumer is often demanding on a high-quality food product that are safe, have natural content and their shelf life has extended time-line. He further stated that, given this demand, major researchers had proffered innovative technology with respect to food as the most potent means of ensuring adequate food production and FSSS.

However, irrespective of the above development in FIT in mitigating the challenges posed by climate change, there is still a need to utilised possible means such as policy or international regulatory frame-work in curtailing the excessive human activities that lead to a harmful climate change that may hamper food production.

\section{Legal frame-work on climate change with respect to FIT}

To ensure a better and effective food development and production [9, 13, 24], it requires a safe and protected climatic condition, free from pollution, depletion of the ozone layer. Furthermore, given the ineffective preservation of land, water, and air from depletion as a result of human activities it has led to the development FIT [6, $58,66]$. However, the global international community has been facing great challenges (climate change) pose by the depletion and degradation of the environment, which serve as a threat to the trending innovative food and technology [[29, 3937,88$]$. It is as a result of the growing concern over the deteriorating climatic conditions that have led to the emergence of an international regulatory regime that sort to address both international and domestic environmental or climatic problems [7, 92], to ensure the preservation and conservation of the climatic environment and to revitalise the trending FIT.

However, despite the international community has giving enormous attention to solving the change in climatic conditions with regard to the formulation of regulatory frame-work, the climatic condition is still not favourable to mankind in food production. Most developing nation such as Nigeria has its own share of climatic change 
challenges which requires local attention [79],[93], [4], of which several laws have been enacted to cater for the problem and challenges posed by the very drastic effect of environmental change [81, 91].

Given the above, some of the appropriate international instruments combating these challenges will be concisely evaluated below in analysing the extent laws have been put in place in regulating climate change in ensuring a better FIT for FSSS.

\section{International regulatory legal framework}

International environmental law [85] has its roots prior to 1950 . Before 1900, there were just a few multilateral or bilateral agreements regulating global ecological issues, such as boundary waters and fishing rights along shared waterways. No attention was given to change in climate resulting from pollution and environmental depletion. However, in the nineteenth century, given the harsh climatic change $[15,22]$, countries started recognising the need to ensure an effective legal frame-work that will protect the climate for a better humankind utilisation, such as the current trend of innovative food technology. Furthermore, it was Rachel Carson's [15] famous book 'Silent Spring' that exposed the hazards of the pesticide DDT (use by most multi-national company), causing environmental havoc on the climatic condition. Her book set the stage for the negotiation of several international environmental treaties to curtail oil pollution casualties, oil pollution damage to the climate, and depletion of the ozone layer. Some of these international legal frameworks related to climate change in FIT will be examined in the following subsections.

\section{The Stockholm convention on persistent organic pollutants}

The United Nations Stockholm Conference was the first International Environmental conference held in 1972 to deal with significant issues affecting the deterioration and depletion of the climate condition caused by human activities (Burns and Osofsky, 2009; [72]. One of such human activities that affect the climate condition was persistent organic pollutants; Persistent organic pollutants are organic (carbon-based) compounds that are made up of synthesized substances (pesticides and PCBs) that are very toxic to the climate condition. However, the Stockholm Convention on persistence organic pollutants was made to mitigate and curtail the excess release of persistent organic pollutants that deplete the climatic condition.

However, the introductory part of the convention provides that the essence of the convention is as a result of the awareness that the persistent organic pollutants have toxic substances that resist degradation and bioaccumulation, and which also have a harmful effect when accumulated in terrestrial, aquatic, and arctic ecosystems. The introduction also captured the fact that the climate is at risk, given the biomagnifications of the persistent organic pollutants that contaminate traditional foods. Furthermore, Article 3 of the Stockholm Convention on Persistent Organic Pollutants requires signatory state to take measures in reducing or eliminating the releases from intentional production and use of the chemicals listed in Annex A. These chemicals include; Aldrin, Dieldrin, Chlordane, Heptachlor, Endrin, Toxaphene, Mirex, and chemicals listed in Annex $B$ of the convention. In addition, in ensuring effective implementation of the Convention. Article 7 of the convention further required parties to the convention to develop and strategies plans for the implementation of their responsibilities as contained in the Convention and to also cooperate with the regional and sub-regional organizations, and consult their national stakeholders to a safe climate free from organic pollutant.

It is relevant to state that the Stockholm Convention has been further improved on as a result of several Conferences held. One such relevant conference meeting was held in Geneva, Switzerland, from 4 to 15th May 2015; the meeting theme was "from science to action, working for a safer tomorrow. Notable decision taken to strengthen the protection of the climate was a further measures strategy eliminate release from waste, evaluation of the continued need for the procedure under Paragraph 2(5) of Article 3, further consideration and reassessment of the use of hexachlorobutadiene.

\section{RIO declaration on environment and development}

The Rio Declaration on the environment is an offshoot of the United Nations Conference on Environment and Development (UNCED), also called the Rio de Janeiro Earth Summit. The essence of the Rio Declaration was aimed at addressing pertinent issues threatening climate earth [57]. Some of these pertinent issues that the Rio Declaration sort of solving as it relates to climate change are summarized below:

- Unsystematic scrutiny of the process of production of toxic components, such as poisonous waste, hazardous waste, lead in gasoline, and radioactive chemicals.

- Using other sources of energy to replace the use of fossil fuels that often lead to global climate change via the emission of GHG.

- Reducing or eliminating the release of vehicle emissions (GHG in particular) that often result in polluted air and modification of the climate system resulting to climate change. 
Nevertheless, the above Principle 1 of the Rio Declaration is to the extent that the concern for sustainable development is very vital to the existence of the climate earth and to prevent harmful climate change. Given the exactitude of principles, Principle 2 of the Rio Declaration further required States to ensure the effective exploitation of their resources and take responsibilities in ensuring that their activities do not affect or cause possible harm to the climate system.

Albeit, it is also pertinent to state that there are other relevant binding conventions, which are aimed at protecting the harmful change in the climate systems that also came into effect during the Rio Conference. Summarily, they include:

- The principles of Agenda 21 recognize that biological diversity is approximately more than just plants, animals, and microorganisms as well as the ecosystems which they live in; it is also about people and their need for medicines, fresh air and water, shelter, a clean and healthy environment to live as well as FSSS.

- The United Nation Framework Convention on Climate Change (UNFCCC) whose definitive objective is to attain the steadying of GHG concentrations within the atmospheric environment at an extent that would avert perilous interference with the climate settings.

- The United Nations Convention to Combat Desertification (UNCCD) who is the only legitimately binding global agreement networking environment and development to sustainable land management aimed at fostering FSSS.

A perusal of the above treaties tends to ensure that there is an adequate measure put in place to savage looming change in climate system that may be very harmful to humans, plants, animals, and the ecosystem in general.

\section{The Kyoto protocol and the Paris climate conference agreement in 2015}

The Kyoto Protocol is an international treaty adopted by member states on $11^{\text {th }}$ December 1997 and came into force on 16th February 2005. The protocol came into effect given the drastic emission or release of greenhouse gasses concentration in the atmosphere (resulting from industrial activities), which further resulted in changes in the climate condition or global warming [12]. However, the Kyoto protocol elaborated on the 1992 UNFCCC that requires member States or Parties to the protocol to eliminate or reduce GHG emissions [51]. In this regard, Article 3 of the Kyoto Protocol provides that only the Annex 1 countries (i.e., developed industrialise countries such as the USA, China, Russia,
Germany, etc.) were required to reduce their rate of greenhouse gas emission by $5.20 \%$. Furthermore, Article 6, 12, and 17 of the Kyoto Protocol also specified developed countries should endeavour to use flexible mechanisms in achieving the ultimate aim of the protocol, which protecting the climate from the hazardous and half effect of the greenhouse gas emission.

However, to ensure continuous efforts of protecting climate earth from harmful human activities, The Paris Climate Conference Agreement in 2015 made to replace the first Kyoto Protocol [116]. The Paris Agreement is an agreement within the frame-work of the UNFCCC governing $\mathrm{CO}_{2}$ reduction measures to be taken in 2020 . The primary legal innovation of the agreement, which relates to climate change on FIT, is as provided in the convention is described in Article 2, which sort to enhancing the implementation of the UNFCCC are summarized below:

- Ensuring that the global average temperature is well below $2.0{ }^{\circ} \mathrm{C}$. The agreement further envisages a zero-net anthropogenic GHG emission to be attained before or during the second half of the twenty-first century.

- The agreement also sorts to ensure zero emissions of GHG between 2030 and 2050, given the fact that it would greatly reduce or possibly eliminate the rate of climate change.

- Ensuring better adaptability to the unfavourable impacts of climate change in an approach that does not threaten or pressure food production.

The above summarized Paris Agreement served as a major turning point in mitigating against climate change or global warming that negatively affects climate earth [31]. However, FIT in the context of FSSS as it relate to climate change have not been given the required attention by most researchers. Most of the reported studies on FIT have been carried with researchers paying much attention to the varieties of foods available with limited consideration on the effects of climatic variables. Hence, there is a need to concentrate attention on other factors beside the different varieties such as the influence of climate change and FIT in conjunction on how these factors over the years have affected the utilization of FIT with respect to FSSS.

\section{The Basel convention and Bamako convention}

The Basel Convention is a United Nations Treaty, and the convention grew out of the increasing awareness of the negative impact of dumping flammable, toxic, explosive, and hazardous waste on climate earth. The Basel Convention aims summarily to do the following: 
- Reduce trans-boundary movements of hazardous waste to a minimum.

- Ensure that hazardous wastes should be treated and disposed of as close as possible to their source of generation.

- Minimize hazardous waste generation at source.

The issue associated with the health menaces ensuing from hazardous waste in the form of environmental adulteration is one of the utmost serious concern to most ecological researchers around the world [3, 107, 114]. According to several reported studies, industrial waste (such as heavy metals and dyes) is one of the core hypothetically environmental noxious waste especially in fluid (air or water in particular) and land (soil), which are added to the already climate influenced ecosystem via some anthropogenic and natural activities. Some of these hazardous waste are currently considered as deadly due to their mobility rate and solubility tendencies $[3,80,107$, 114].

Given the above, Annex 1 and III of the Basel Convention states that wastes listed that possess the character of been contagious and hazardous to the climate should be treated and eliminated. In furtherance of the Basel Convention, then the following obligation was required to be observed by member's state; Article 2 of the Basel Convention required that contracting parties should ensure that steps are taken to curtail the movement of hazardous waste across the international boundary. However, Article 12 of the Convention further directs parties to adopt a protocol that establishes liability rules and procedures appropriate for damage resulting from hazardous waste movement across borders.

However, in the Basel Convention, there were no provisions for sanction and punishment on erring members' state. Given the legal anomalies inherent in the Basel Convention, The African countries came up with a convention known as the Bamako Convention on the Importation and Control of Trans-Boundary Movement of Hazardous waste within Africa. In this regard, Article 4(3) (c) of the Bamako Convention provides that the generation of harmful and hazardous wastes within African states reduces to a minimum, taking into account the global environment. Furthermore, Article 4(3) (b) of the Bamako Convention imposes stringent and strict unlimited liability as well as joint and several liabilities on hazardous waste generators. Article 9 (4) of the Convention provides that a transboundary movement of hazardous wastes is deemed to be illegal traffic. The state of import shall ensure that the wastes in question are returned to the exporting countries and that legal action as provided for in the Bamako Convention are taken against the contravener(s).
Given the above international legal framework on climate change, it suffices that the international community has been taking legal precautions in combating and mitigating challenges in correcting the current climate change. The scientist has warned that if nothing is done in rectifying the current climate change, agricultural production of food will be severely hampered. Hence, the use of contemporary and evolving materials (such nanomaterials) and scientific techniques (such as AI and IoT) in aspect of FIT that are cost effective and environmental friendly are highly encouraged and such should be evolved [53, 107, 114].

\section{Conclusion}

The current accelerated changes in the climatic conditions have aggravated prevailing environmental and climatic complications in almost if not all the regions of the world, that are instigated by the combination of variations in land use, increasing contamination and deteriorating biodiversity. In most affected domains (such as water, agricultural processes, ecosystems, health, FSSS), present modification and future circumstances dependably point to substantial and increasing hazards during the upcoming years, of which some of these impacts are diverse and remarkably ambiguous. The application of FIT and CCA guidelines and strategies to agricultural processes will be of great response and assistance in the mitigation of the undesirable effects of the changes in the climatic conditions. Hence, in this study a brief review of some of the current developments in agricultural processes with reverence to the effect of climate change on FIT have been presented. In addition, some legal framework on climate change as it relates to FIT are also discussed.

Policies, approaches, laws (legal framework), guidelines and strategies on climate change for the sustainable advancement or development of every region need to alleviate these ensuing environmental hazards of climate change, potentially by considering he FIT and CCA options such as CSA. However, it would be somehow difficult to practise, adopt and adapt these options due to the current inadequate information, mostly for the most vulnerable regions in underdeveloped and developing nations, where there are little or no systematic observations systems and impact models.

Since it is believed that there is hardly a single region especially the underdeveloped and developing nations that has sufficient and adequate resources both human and capital in managing and coping with the accelerated rate and pace in the changes of the climatic and environmental conditions on its own. Therefore, it is suggested that our mutual efforts in the upcoming years should concentrate on means of fronting these critical climatic situations by 
re-evaluating our approaches, policies, laws (legal framework), guidelines and strategies on climate change specifically in line with the SDGs, in all regions especially these regions with the most inadequate resources (such as the underdeveloped and developing nations) in the perspective of FIT designed for fostering FSSS in particular.

\section{Acknowledgements}

The authors are unaffectedly thankful to the management and staff of Edo State University Uzairue, Nigeria, the editorial team of Agriculture \& Food Security, the anonymous reviewers, and the Springer Nature Waivers Team, as well as authors and agencies whose publications and articles were used for this study.

\section{Authors' contributions}

KEU Conceptualization, Investigation, Methodology, Project administration, Resources, Supervision, Validation, Writing —original draft, Writing —review and editing. PAA: Conceptualization, Investigation, Methodology, Validation, Writing - original draft, Writing — review and editing. Both authors read and approved the final manuscript.

\section{Authors' information}

Kingsley Eghonghon Ukhurebor is a Lecturer/Researcher presently at the Department of Physics, Edo State University Uzairue, Nigeria. He has a Ph.D. in Physics Electronics from the University of Benin, Benin City, Nigeria. He is a Research Fellow at the West African Science Service Center on Climate Change and Adapted Land (WASCAL), Competence Center, Ouagadougou, Burkina Faso. He is also a prospective Postdoctoral Fellow of the the World Academy of Sciences - COMSATS University Islamabad, Pakistan (TWAS-CUI). $\mathrm{He}$ is a member of several learned academic organizations. His research interests are Applied Physics, Climatic Physics, Environmental Physics, Telecommunication Physics and Material Science. He serves as editor and reviewer to several reputable journals. He has authored and co-authored several research articles and other publications.

Paul Atagamen Aidonojie is a Lecturer/Researcher presently at the Faculty of Law, Edo State University Uzairue, Nigeria. He is at the concluding stage of his Ph.D. in Law. He has authored and co-authored several research articles.

\section{Funding}

This study has not received any specific grant from funding agencies in the public, commercial, or not-for-profit sectors.

\section{Availability of data and materials}

Not applicable.

\section{Declarations}

Ethics approval and consent to participate Not applicable.

\section{Consent for publication}

Not applicable.

\section{Competing interests}

The authors (Kingsley Eghonghon Ukhurebor and Paul Atagamen Aidonojie) declare that they have no known competing financial interests or personal relationships that could have appeared to influence the work reported in this article.

\section{Author details}

${ }^{1}$ Department of Physics, Edo State University Uzairue, P.M.B. 04, Auchi, Edo State, Nigeria. ${ }^{2}$ Faculty of Law, Edo State University Uzairue, P.M.B. 04, Auchi, Edo State, Nigeria

Received: 8 April 2021 Accepted: 8 July 2021

Published online: 02 December 2021

\section{References}

1. Abdulkadir BA. The right to a healthful environment in Nigeria: a review of alternative pathways to environmental justice in Nigeria Afe Babalola University. J Sustain Develop Law Policy. 2014;3(1):13.

2. Adenle AA, Azadi H, Arbiol J. Global Assessment of technological innovation forclimate change adaptation and mitigation in developing world. J Environ Manage. 2015;161:261-75.

3. Aigbe UO, Onyancha RB, Ukhurebor KE, Obodo KO. Removal of fluoride ions using polypyrrole magnetic nanocomposite influenced by rotating magnetic field. RSC Advance. 2020;10(1):595-609.

4. Akamabe UB, Kpae G. A critique on Nigeria national policy on environment: reasons for policy review. IIARD Int J Geography Environ Manag. 2017:3(3):22-36.

5. Anderson PK, Cunningham AA, Patel NG, Morales FJ, Epstein PR, Daszak P. Emerging infectious diseases of plants: pathogen pollution, climate change and agrotechnology drivers. Trends Ecol Evol. 2004;19(10):535-44

6. Arshney RK, Bansal KC, Aggarwal PK, Datta SK, Craufurd PQ. Agricultural biotechnology for crop improvement in a variable climate: hope or hype? Trends Plant Sci. 2011;16(7):363-71.

7. Atsegbua L, Akpotaire V, Dimowo F. Environmental Law in Nigeria, Theory and Practicals. 2nd ed. Lagos Ambik Press; 2004; 280.

8. Avnery S, Mauzerall DL, Liu JF, Horowitz LW. Global crop yield reductions due to surface ozone exposure: 1. Year 2000 crop production losses and economic damage. Atmos Environ. 2011;45(13):2284-96.

9. Bai ZG, Dent DL, Olsson L, Schaepman ME. Proxy global assessment of land degradation. Soil Use Manag. 2008;24(3):223-34.

10. Battisti DS, Naylor RL. Historical warnings of future food insecurity with unprecedented seasonal heat. Science. 2009;323(5911):240-4.

11. Beddington JR, Asaduzzaman M, Clark ME, Bremauntz AF, Guillou MD, Jahn MM, Lin E, Mamo T, Negra C, Nobre CA, Scholes RJ, Sharma R, Van Bo N, Wakhungu J. The role for scientists in tackling food insecurity and climate change. Agric Food Security. 2012;1(1):1-9.

12. Bodansky D, Brunnee J, Rajamani L. International Climate Change Law. Oxford University Press; 2017.

13. Bridges EM, Oldeman LR. Global assessment of human-induced soil degradation. Arid Soil Res Rehabil. 1999;13(4):319-25.

14. Busse M, Siebert R. The role of consumers in food innovation processes. Eur J Innov Manag. 2018;21(1):20-43. https://doi.org/10.1108/ EJIM-03-2017-0023.

15. Carson R. The Story of Silent Spring. 1962. http://www.nrdc.org/health/ pesticides/hcarson.asp. Accessed 28 Jan 2021.

16. Challinor AJ, Müller C, Asseng S, Deva C, Nicklin KJ, Wallach D, Vanuytrecht E, Whitfield S, Ramirez-Villegas J, Koehler AK. Improving the use of crop models for risk assessment and climate change adaptation. Agric Syst. 2018;159:296-306.

17. Chapman SC, Chakraborty S, Dreccer MF, Howden SM. Plant adaptation to climate change opportunities and priorities in breeding. In: Crop and Pasture Science. CSIRO Publishing, Collingwood. 2012; 63: 251-268.

18. Chen HD, Weiss JC, Shahidi F. Nanotechnology in nutraceuticals and functional foods. Food Technol J. 2006:60:30-6.

19. Chen JH, Ren Y, Seow J, Liu T, Bang WS, Yuk HG. Intervention technologies for ensuring microbiological safety of meat: current and future trends. Compr Rev Food Sci Food Safety. 2012;11(2):119-32.

20. Childers DL, Corman J, Edwards M, Elser JJ. Sustainability challenges of phosphorus and food: solutions from closing the human phosphorus cycle. Bioscience. 2011;61(2):117-24.

21. Christensen JL, Rama R, Von Tunzelmann N. Study on Innovation in the European Food Products and Beverages Industry. Brussels: Report for the European Commission Sprint Programme; 1996.

22. Chukwuemeka CE. Deficient legislation sanctioning oil spill in nigeria: a need for a review of the regulatory component of petroleum laws in Nigeria and the petroleum industries bill. Int J Environ Sustain. 2018;7(1):30-44.

23. Colurcio M, Wolf $P$, Kocher $P$, Russo ST. Asymmetric relationships in networked food innovation processes. Br Food J. 2012;114(5):702. https:// doi.org/10.1108/00070701211229981.

24. Cordell D, Drangert JO, White S. The story of phosphorus: global food security and food for thought. Global Environ Change-Human and Policy Dimensions. 2009;19(2):292-305. 
25. Dallmann I. Weather variations and international trade. Environ Resource Econ. 2019;72(1):155-206. https://doi.org/10.1007/ s10640-018-0268-2.

26. Deliza R, Rosenthal A, Silva ALS. Consumer attitude towards information on non- conventional technology. Trends Food Sci Technol. 2003;14:43-9.

27. Dijkstra JA, Westerman EL, Harris LG. The effects of climate change on species composition, succession and phenology: a case study. Glob Change Biol. 2011;17:2360-9.

28. Earle MD. Innovation in the food industry. Trends Food Sci Technol. 1997:8(5):166-75. https://doi.org/10.1016/S0924-2244(97)01026-1.

29. Eckersten $H$, Herrmann $A$, Kornher A, Halling M, Sindhøj E, Lewan E. Predicting silage maize yield and quality in Sweden as influenced by climate change and variability. Acta Agriculturae Scandinavica, Section B Soil Plant Sci. 2011;62(2):151-65.

30. EPA. Inventory of U.S. Greenhouse Gas Emissions and Sinks. 2020; https://www.epa.gov/ghgemissions/inventory-us-greenhouse-gasemissions-and-sinks Accessed 27 Jan 2021

31. Falkner R. The Paris agreement and the new logic of international climate politics. Int Aff. 2016:92(5):1107-25.

32. FAO. Fishery and Aquaculture Statistics. Global Production by Production Source 1950- 2015 (FishStatJ). In: FAO Fisheries and Aquaculture Department. 2017a. Rome, Italy http://www.fao.org/fishery/statistics/ en. Accessed 25 Jan 2021

33. FAO. The Future of Food and Agriculture - Trends and Challenges. 2017b. Rome, Italy http://www.fao.org/3/a-i6583e.pdf. Accessed 27 Jan 2021.

34. Fisher M, Abate T, Lunduka RW, Asnake W, Alemayehu Y, Madulu RB. Drought tolerant maize for farmer adaptation to drought in Sub-Saharan Africa: Determinants of Adoption in Eastern and Southern Africa. Clim Chang. 2015:133:283-99.

35. FOA. High Level Expert Forum - How to Feed the World in 2050. 2009 Rome, Italy. http://www.fao.org/fileadmin/user_upload/lon/HLEF2050 Global_Agriculture.pdf. Accessed 27 Jan 2021.

36. Gallic E, Vermandel G. Weather shocks. Eur Econ Rev. 2020;124: 103409. https://doi.org/10.1016/j.euroecorev.2020.103409.

37. Garrett KA, Forbes GA, Savary S, Skelsey P, Sparks AH, Valdivia C. Complexity in climate-change impacts: an analytical framework for effects mediated by plant disease. Plant Pathol. 2011;60(1):15-30.

38. Gedan KB, Bertness MD. How will warming affect the salt marsh foundation species spartina patens and its ecological role? Oecologia. 2010;164:479-87.

39. Githeko AK, Lindsay SW, Confalonieri UE, Patz JA. Climate change and vector-borne diseases: a regional analysis. Bull World Health Organ. 2000;78(9):1136-47.

40. Grunert KG, Harmsen H, Meulenberg M, Kuiper E, Ottowitz T, Declerck F, Traill B, Göransson G. A framework for analysing innovation in the food sector. In: Traill B, Grunert KG, editors. Products and Process Innovation in the Food Industry. Springer, Boston, MA; 1997. pp. 1-37. https://doi. org/10.1007/978-1-4613-1133-1_1.

41. Guo $\mathrm{C}$, Xiao $H$, Yang $H$, Wen W. Effects of anthropogenic aerosols on a heavy rainstorm in Beijing. Atmosphere. 2019;10(4):162.

42. Hansen JW, Baethgen W, Osgood D, Ceccato P, Ngugi RK. Innovations in climate risk management: protecting and building rural livelihoods in a variable and changing climate. J Semi-Arid Trop Agric Res. 2007:4:1-38.

43. Helmuth B, Babij E, Duffy E, Fauquier D, Graham M, Hollowed A, Howard J, Hutchins D, Jewett L, Knowlton N, Kristiansen T, Rowles, T, Sanford E, Thornber C, Wilson C. Impacts of Climate Change on Marine Organisms. In: Griffis R, Howard J. (Editors). Oceans and Marine Resources in a Changing Climate. NCA Regional Input Reports. Island Press, Washington, DC; 2013. https://doi.org/10.5822/978-1-61091-480-2_3.

44. Herndon JM. Science misrepresentation and the climate science cartel. J Geography Environ Earth Sci Int. 2018;18(2):1-13.

45. Herndon JM. Role of atmospheric convection in global warming. Geograph Environ Earth Sci Int. 2019;19(4):1-8.

46. Herndon JM, Whiteside M. Further evidence that particulate pollution is the principal cause of global warming: humanitarian considerations. J Geo Environ Earth Sci Int. 2019;21(1):1-11.

47. International the News. Climate Change Hit Poorest Countries Hardest Last Year: Report. News Report.
Change-hit-poorest-countries-hardest-last-year-report. 2021. https:// www.thenews.com.pk/print/780130-climate. Accessed 28 Jan 2021.

48. IPCC. Synthesis Report, Contribution of Working Groups I, II, and III to the Third Assessment Report of the Intergovernmental Panel on Climate Change. Cambridge University Press, United Kingdom. 2001. https://www.ipcc.ch/site/assets/uploads/2018/03/front-1.pdf. Accessed 22 Jan 2021.

49. IPCC. Impacts, Adaptation, and Vulnerability. Part A: Global and Sectoral Aspects. Contribution of Working Group II to the Fifth Assessment Report of the Intergovernmental Panel on Climate Change. Cambridge University Press: Cambridge, UK; New York, NY, USA. 2014. https://envir onmentalmigration.iom.int/climate-change-2014-impacts-adaptationandvulnerability-contribution-working-group-ii-fifth. Accessed 24 Jan 2021.

50. Jianli L, Hongdong G, Fu J. Technological innovation in agricultural cooperatives in china: implications for agro-food innovation policies. Food Policy. 2017;73:19-33. https://doi.org/10.1016/j.foodpol.2017.09.001.

51. Jon H, Detlef FS, Guri B. Why the United States did not become a party to the Kyoto Protocol: German, Norwegian, and US perspectives. Eur J Int Rel. 2010;18(1):129-50. https://doi.org/10.1177/1354066110380964.

52. Kaddo JR. Climate Change: Causes, Effects, and Solutions. 2016. https:// spark.parkland.edu/ah/164/. Accessed 27 Jan 2021.

53. Kerry RG, Ukhurebor KE, Kumari S, Maurya GK, Patra S, Panigrahi B, Majhi S, Rout JR, Rodriguez-Torres MDP, Das G, Shin H-S, Patra JK. A Comprehensive review on the applications of nano-biosensor based approaches for non-communicable and communicable disease detection. Biomater Sci. 2021:9:3576-602.

54. Kinney AJ. Development of genetically engineered soybean oils for food applications. J Food Lipids. 1996:3:273-92.

55. Komar N, Zeebe RE, R.E., . Reconciling atmospheric $\mathrm{CO}_{2}$, weathering, and calcite compensation depth across the cenozoic. Sci Adv. 2021. https://doi.org/10.1126/sciadv.abd4876.

56. Kourkoutas Y, Chorianopoulos N, Nisiotou A, Valdramidis VP, Karatzas KAG. Application of innovative technologies for improved food quality and safety. Biomed Res Int. 2016. https://doi.org/10.1155/2016/91603 75.

57. Ladychenko V, Melnychuk O, Kanaryk YJ. International mechanism of the environmental information access and cooperation framework for climate change protection. Eur J Sustain Develop. 2019;8(4):131-41.

58. Lobell DB, Burke MB, Tebaldi C, Mastrandrea MD, Falcon WP, Naylor RL. Prioritizing climate change adaptation needs for food security in 2030 Science. 2008;319(5863):607-10.

59. Mackey M, Montgomery J. Plant biotechnology can enhance food security and nutrition in the developing world part 1. Nutr Today. 2004;39:52-8.

60. Maryanski JH. Special challenges of novel foods (biotechnology). Food Drug Law J. 1990:45:545-50.

61. McCullum C, Benbrook C, Knowles L, Roberts S. T. Application of modern biotechnology to food and agriculture: food systems perspective. J Nutr Educ Behav. 2003;35:319-32.

62. Meena RS, Kumar S, Datta R, Lal R, Vijayakumar V, Brtnicky M, Sharma MP, Yadav GS, Jhariya MK, Jangir CK, Pathan SI. Impact of agrochemicals on soil microbiota and management: a review. Land. 2020;9(2):34.

63. Mendelsohn RO, Nordhaus WD, Shaw D. The impact of global warming on agriculture: a ricardian analysis. The American economic review. 1994. 753-771.

64. Michelle W, Carlos MD, Tim JBC, Robert JO, William D, Suzanne O, Ainsley C, James WF, Kenneth LH, Randall H, Gary A, Kendrick JWK, Frederick T, S., Suasn, L. W. . Accelerating loss of seagrasses across the globe threatens coastal ecosystems. Proc Natl Acad Sci. 2009;106(30):1237781. https://doi.org/10.1073/pnas.0905620106.

65. Mikler J, Harrison NE. Varieties of capitalism and technological innovation for climate change adaptation. New Political Econ. 2012;17(2):179-208

66. Miraglia M, Marvin HJ, Kleter GA, Battilani P, Brera C, Coni E. Climate change and food safety: an emerging issue with special focus on Europe. Food Chem Toxicol. 2009;47(5):1009-21.

67. Mmadu R. Judicial attitude to environmental litigation and access to environmental justice in Nigeria: lessons from Kiobel Afe Babalola University. J Sustain Develop Law Policy. 2013;2(1):8. 
68. Moraru Cl, Panchapakesan CP, Huang QR, Takhistov P, Liu S, Kokini JL. Nanotechnology: a new frontier in food science. Food Technol. 2003;57:24-9.

69. Morrissey S. Nanotechnology in food and agriculture. Chem Eng News. 2006:84:31-31.

70. Muluneh A, Bewket W, Keesstra S, Stroosnijder L. Searching for evidence of changes in extreme rainfall indices in the central rift valley of Ethiopia. Theor Appl Climatol. 2017;128(3-4):795-809.

71. Muluneh A, Biazin B, Stroosnijder L, Bewket W, Keesstra S. Impact of predicted changes in rainfall and atmospheric carbon dioxide on maize and wheat yields in the central rift valley of Ethiopia. Reg Environ Chang. 2015;15(6):1105-19.

72. Musa A, Bappah H. Issues and challenges on environmental rights: the Nigerian experience. Am Int J Social Sci. 2014;3(5):14

73. Nout MJR, Motarjemi Y. Assessment of fermentation as a household technology for improving food safety: A joint FAO/WHO workshop. Food Control. 1997;8:221-6.

74. Nwankwo W, Olayinka SA, Ukhurebor KE. Green computing policies and regulations: a necessity? Int J Sci Technol Res. 2020;9(1):4378-83.

75. Nwankwo W, Ukhurebor KE. An x-ray of connectivity between climate change and particulate pollutions. J Adv Res Dynamical Control Syst. 2019;11(8):3002-11.

76. Nwankwo W, Ukhurebor KE. Investigating the performance of point to multipoint microwave connectivity across undulating landscape during rainfall. J Nigerian Soc Physical Sci. 2019;1(3):103-15.

77. Nwankwo W, Ukhurebor KE. Big data analytics: a single window loTenabled climate variability system for all-year-round vegetable cultivation. IOP Conference Series Earth Environ Sci. 2021;655:012030.

78. Ogunniran BI. Ozone layer depletion and climate change in Nigeriaproblems and prospects: a review. Glob. J Res Rev 2018. 5(1:2).

79. Olowoporoku OA. A recipe for disaster: an assessment of environmental sanitation situation in Nigeria. MAYFEB J Environ Sci. 2017;1:1-5.

80. Onyancha RB, Aigbe UO, Ukhurebor KE, Muchiri PW. Facile synthesis and applications of carbon nanotubes in heavy-metal remediation and biomedical fields: a comprehensive review. J Mol Struct. 2021;1238:130462.

81. Orimoloye EO, Amadi COA, Amadi AN, Azuamah YC, Nwoke EA, Zacchaeus U, Dozie INS. Assessment of water sanitation and hygiene practices in Ibadan. Nigeria Int J Res. 2015;2(2):94-100.

82. Osofsky HM, Burns WCG. Adjudicating Climate Change: State, National, and International Approaches. Cambridge University Press; 2009.

83. Pandolfi JM, Connolly SR, Marshall DJ, Cohen AL. Projecting coral reef futures under global warming and ocean acidification. Science. 2011;333:418-22.

84. Parvatha PR. Climate Resilient Agriculture for Ensuring Food Security. New Delhi: Springer; 2014. p. 1-15.

85. Peter HS. The Evolution of International Environmental Law. The Oxford Handbook of international law, Edited by Bodansky D, Brunnce J, Hey E. 2012. www.oxfordhandbooks.com/.../oxford. Accessed 28 Jan 2021.

86. Peter JF, Cornelis V. Processing technology innovation in the food industry. Innovation. 2008;10(1):74-90. https://doi.org/10.5172/impp. 453.10.1.74

87. Pielke RA, Adegoke JO, Chase TN, Marshall CH, Matsui T, Niyogi D. A new paradigm for assessing the role of agriculture in the climate system and in climate change. Agric Meteorol. 2007;142:234-54.

88. Pimentel D. Soil erosion: a food and environmental threat. Environ Dev Sustain. 2006:8(1):119-37.

89. Pothakamury UR, BarbosaCanovas GV. Fundamental aspects of controlled release in foods. Trends Food Sci Technol J. 1995;6:397-406.

90. Ramirez-Villegas J, Watson J, Challinor AJ. Identifying traits for genotypic adaptation using crop models. J Exp Bot. 2015;66:3451-62.

91. Robinson JO. Environmental education and sustainable development in Nigeria: breaking the missing link. Int J Edu Res. 2013;1(5):1-16.

92. Saka L, Salihu HA, Ali AA. Environmental degradation, rising poverty and conflicts: towards an explanation of the Niger Delta crisis. J Sustain Develop Africa. 2007;9(4):8.

93. Sambe LN, Adeofun CO, Dachung G. The economic and ecological effects of deforestation on the Nigerian environment. Asian J Adv Res Rep. 2018;1(2):1-25.
94. Santeramo FG, Miljkovic D, Lamonaca E. Agri-food trade and climate change. Economia agro-alimentare/Food Economy. 2021. https://mpra. ub.uni-muenchen.de/106754/. Accessed 9 June 2021.

95. Siloko IU, Ukhurebor KE, Siloko EA, Enoyoze E, Ikpotokin O. The interactions between temperature and relative humidity: results for Benin City, Nigeria using statistical analysis. Curr Appl Sci Technol. 2022;22(1):857565.

96. Steenwerth KL, Hodson AK, Bloom AJ, Carter MR, Cattaneo A, Chartres CJ, Hatfield JL, Henry K, Hopmans JW, Horwath WR, Jenkins BM, Kebreab E, Leemans R, Lipper L, Lubell MN, Msangi S, Prabhu R, Reynolds MP, Solis SS, Sischo WM, Springborn M, Tittonell P, Wheeler SM, Vermeulen SJ, Wollenberg EK, Jarvis LS, Jackson LE. Climate-smart agriculture global research agenda: scientific basis for action. Agric Food Security. 2014;3(1):1-39.

97. Sumaila UR, Cheung W, Lam VWY, Pauly D, Herrick S. Climate change impacts on the biophysics and economics of world fisheries. Nat Clim Chang. 2011;1:449-56.

98. Sundström JF, Albihn A, Boqvist S, Ljungvall K, Marstorp $H$, Martiin C, Nyberg K, Vågsholm I, Yuen J, Magnusson U. Future threats to agricultural food production posed by environmental degradation, climate change, and animal and plant diseases - a risk analysis in three economic and climate settings. Food Sec. 2014;6:201-15. https://doi. org/10.1007/s12571-014-0331-y.

99. Sweileh WM. Bibliometric analysis of peer-reviewed literature on food security in the context of climate change from 1980 to 2019. Agric Food Security. 2020;9(1):1-15.

100. Tambo JA, Abdoulaye T. Climate change and agricultural technology adoption: the case of drought tolerant maize in rural Nigeria. Mitig Adapt Strateg Glob Chang. 2012;17:277-92.

101. Tester M, Langridge P. Breeding technologies to increase crop production in a changing world. Science. 2010;327:818-22.

102. Timmer CP. Biotechnology and food systems in developing countries. J Nutr. 2003;133:3319-22.

103. Ukhurebor KE, Adetunji CO. Relevance of biosensor in climate smart organic agriculture and their role in environmental sustainability: what has been done and what we need to do. In: Pudake RN, Jain U, Kole C. (Editors). Biosensors in Agriculture: Recent Trends and Future Perspectives. Concepts and Strategies in Plant Sciences. Springer, Cham. 2021 115-136. https://doi.org/10.1007/978-3-030-66165-6_7.

104. Ukhurebor KE, Aigbe UO, Onyancha RB, Adetunji CO. Climate change and pesticides: their consequence on microorganisms. In: Adetunji CO, Panpatte DG, Jhala YK, Editors. Microbial Rejuvenation of Polluted Environment. Microorganisms for Sustainability. Springer, Singapore. 2021a. 27: 83-113. https://doi.org/10.1007/978-981-15-7459-7_5.

105. Ukhurebor KE, Aigbe UO, Onyancha RB, Nwankwo W, Osibote OA, Paumo HK, Ama OM, Adetunji CO, Siloko IU. Effect of hexavalent chromium on the environment and removal techniques: a review. J Environ Manag. 2021d. 280: 111809

106. Ukhurebor KE, Abiodun IC. Variation in annual rainfall data of forty years (1978-2017) for South-South, Nigeria. J Appl Sci Environ Manag. 2018;22(4):511-8.

107. Ukhurebor KE, Athar H, Adetunji CO, Aigbe UO, Onyancha RB, Abifarin O. Environmental implications of petroleum spillages in the Niger Delta region of Nigeria: a review. J Environ Manag. 2021;293:112872.

108. Ukhurebor KE, Azi SO. Review of methodology to obtain parameters for radio wave propagation at low altitudes from meteorological data: new results for Auchi area in Edo State, Nigeria. Journal of King Saud University Science. 2019. 31(4); 1445-1451.

109. Ukhurebor KE, Azi SO, Abiodun IC, Ojiemudia SE. Influence of weather variables on atmospheric refractivity over Auchi, South-South, Nigeria. J Appl Sci Environ Manag. 2018;22(4):471-5.

110. Ukhurebor KE, Azi SO, Aigbe UO, Onyancha RB, Emegha JO. Analysing the uncertainties between reanalysis meteorological data and ground measured meteorological data. Measurement. 2020;165:0108110.

111. Ukhurebor KE, Mishra P, Mishra RR, Adetunji CO. Nexus between climate change and food innovation technology: recent advances. In: Mishra P, Mishra RR, Adetunji CO, Editors. Innovations in Food Technology. Springer, Singapore. 2020b. 289-299. https://doi.org/10.1007/978-98115-6121-4_20. 
112. Ukhurebor KE, Nwankwo W. Estimation of the refractivity gradient from measured essential climate variables in lyamho-Auchi, Edo State South-South region of Nigeria. Indonesian J Electrical Engin Comput Sci. 2020;19(1):276-84.

113. Ukhurebor KE, Olayinka SA, Nwankwo W, Alhasan C. Evaluation of the effects of some weather variables on UHF and VHF receivers within Benin City, South-South region of Nigeria. J Phy IOP Conference Series. 2019;1299:012052.

114. Ukhurebor KE, Singh KRB, Nayak V, UK-Eghonghon, G., Influence of SARS-CoV-2 pandemic: a review from the climate change perspective. Environmental Science: Processes \& Impacts; 2021. https://doi.org/10. 1039/D1EM00154J.

115. Ukhurebor KE, Umukoro OJ. Influence of meteorological variables on UHF radio signal: recent findings for EBS, Benin City, South-South, Nigeria. IOP Conference Series Earth Environ Sci. 2018;173:012017.
116. Yamin F, Depledge J. The International Climate Change Regime: A Guide to Rules. Institutions and Procedures: Cambridge University Press; 2004.

117. Yohannes H. A Review on Relationship between climate change and agriculture. J Earth Sci Climate Change. 2016;7(2):1-8.

118. Yun-Hwa PH, Jack AO. Innovations in food technology for health. Asia Pac J Clin Nutr. 2007;16(Suppl 1):65-73.

119. Zvauya R, Muzondo MI. Reduction of cyanide levels in cassava during sequential sundrying and solid-state fermentation. Int J Food Sci Nutr. 1995;46:13-6.

\section{Publisher's Note}

Springer Nature remains neutral with regard to jurisdictional claims in published maps and institutional affiliations.
Ready to submit your research? Choose BMC and benefit from:

- fast, convenient online submission

- thorough peer review by experienced researchers in your field

- rapid publication on acceptance

- support for research data, including large and complex data types

- gold Open Access which fosters wider collaboration and increased citations

- maximum visibility for your research: over 100M website views per year

At BMC, research is always in progress.

Learn more biomedcentral.com/submissions 